\title{
Occupational safety and health in shared workplaces according to workplace inspection reports
}

\author{
Päivi Kekkonen ${ }^{\text {a*, }}$, Arto Reiman ${ }^{\mathrm{a}}$, Seppo Väyrynen ${ }^{\mathrm{a}}$ and Hanna-Kaisa \\ Rajala $^{\mathrm{b}}$ \\ ${ }^{a}$ Industrial Engineering and Management, University of Oulu, Oulu, Finland; \\ ${ }^{b}$ Occupational Safety and Health Section, Regional State Administrative Agency of \\ Northern Finland, Finland
}

*Corresponding author: Päivi Kekkonen, University of Oulu, Industrial Engineering and Management, P.O. Box 4610, FI-90014 University of Oulu, Oulu, Finland. Email: paivi.kekkonen@oulu.fi

\begin{abstract}
The aim of this study was to create a holistic view of shared workplaces and the ways in which these 'special situations' for organizing work take place in practice. The characteristics of shared workplaces and the associated phenomena and challenges were also points of interest. Occupational safety and health inspection reports $(\mathrm{N}=200)$ from the Regional State Administrative Agency of Finland were analysed to obtain information on the deficiencies observed in shared workplaces. The observations were categorized, and the categories were linked to the elements in the work system model. Thus, observation profiles for shared workplaces in the construction, manufacturing and mining and quarrying industries were created. In the observation profiles, significant differences were identified between two or more industries in terms of deficiencies related to organization, employee, task, tools and technology as well as work environment, i.e., the elements comprising the work system model.
\end{abstract}

Keywords: shared workplace, occupational safety and health, workplace inspection, work system

\section{Introduction}

Over the last decades, the number of workplaces in which there are employees of several different employers has increased as organizations focus on their core businesses and subcontract many support services [1]. This has created many shared workplaces where the cooperation of several actors is necessary to ensure the safety and health of all personnel.

This development has resulted in networks and work environments that rely heavily on the cooperation of the companies which are involved [2]. In most cases, the outsourced operations are 'support operations' that are needed to run the core operations of the company [3]. Support operations cover services such as financial administration, 
security and maintenance of the premises and machinery. Outsourcing support operations can be seen as an opportunity for a company to focus on its core operations and, thus, to gain business advantages by concentrating on its area of expertise [4].

The concept of the shared workplace is not yet widely known around the world, and few studies have focused on the safety of shared workplaces [5,6]. However, the various ways of organizing work create challenges related to safety management in all industrialized countries [5]. A review of the literature on this topic highlighted the paucity of related research but also revealed several terms in addition to 'shared workplace' (or workplace). These terms that are used in international legislation and the international literature to refer to a similar arrangement include multi-employer worksite, outsourced work and 'employers sharing a workplace'. In addition, many terms are used to refer to the various actors in a shared workplace. The principal employer of the workplace can also be called a principal company, principal contractor, main company, main authority, main operator, host employer, hosting organization, customer or service purchaser because of its role as a purchaser of the services offered by the service delivering company. The service delivering company, in turn, can also be called a service supplier, supplier, supplying company, external supplier, provider, contractor or subcontractor, or even a partner or an operator [3,7].

The developments of the last decades have given rise to situations and worksites that do not meet the strict definition of a shared workplace but possess similar characteristics with regard to the employers and their employees [8,9]. For example, in industrial parks and shopping centres, there is usually no principal employer, which is an essential factor in shared workplaces. The concept of a shared service centre (SSC) is used especially in the public sector in situations where support processes are 'outsourced' to a separate organizational unit or subdivision that is aligned with external competitors and is operated like a business [1]. In this case, ultimately, the employer of both the core and the support processes can be the same; thus, the definition of a shared workplace is again not met.

The work system model was used as a theoretical framework for this study. The concept of the work system enables the examination of the situation in shared workplaces from a holistic, human-centred perspective [10-12]. Using workplace inspection reports, this study aimed to determine the status of occupational safety and health (OSH) in shared workplaces. The following are the research questions:

(1) What kinds of OSH challenges exist in shared workplaces?

(2) How do the situations of special work take place in practice when viewed from the standpoints of the various actors involved?

(3) What are the special characteristics, situations and phenomena related to shared workplaces in different branches of industries? 


\section{Background}

\subsection{Shared workplace}

The European Union (EU) directives on safety and health at work address a situation similar to that of a shared workplace; however, the OSH Framework directive does not provide much detail. It states:

Where several undertakings share a work place, the employers shall cooperate in implementing the safety, health and occupational hygiene provisions and, taking into account the nature of the activities, shall coordinate their actions in matters of the protection and prevention of occupational risks, and shall inform one another and their respective workers and/or workers' representatives of these risks. [13,p.6].

The roles and responsibilities of different actors on a construction site are also addressed in the individual directive on temporary or mobile construction sites [14].

The Finnish interpretation of the directive is presented in the Occupational Safety and Health Act [15] in national legislation. This defines the shared workplace as a workplace where one employer exercises the main authority and more employers than one, or more self-employed workers than one, operate simultaneously or successively in such a way that the work may affect other employees' safety or health. The legislation states that the employers and self-employed workers at such a workplace shall each and together, through information and adequate mutual cooperation, ensure that their activities do not endanger employee safety and health. The concept of a shared workplace has been included in the Finnish legislation and occupational accident investigation since the early 1990s.

Shared workplaces are situated in the construction, manufacturing and transportation and storage industries in particular. In the construction industry, in particular, almost all of the workplaces can be considered shared workplaces. At large construction sites, there are always employees of several different employers working on their specific areas of expertise, thereby making the site a shared workplace [16]. In addition, in the process and manufacturing industries, it is common for the tasks related to the maintenance of complicated processes to be performed by several smaller companies. In transportation, shared workplaces are common in large hubs and nodes, such as ports, airports as well as other terminals and storage facilities for ground transportation [17-19].

The challenges in shared workplaces that had been recognized in earlier research have been reviewed by Nenonen [6], who categorizes the commonly appearing challenges as related to the factors presented in Table 1 . These include the selection and agreements related to service providers and suppliers, resources, responsibilities and safety management, the identification of hazardous work tasks and practices, the flow of information and communication, and the attitudes and working culture as well as competence and training of the employees. 
Hazardous situations in shared workplaces often arise because work tasks are carried out simultaneously or sequentially by employees of different companies. Work done earlier or by a different company can lead to accidents; thus, the coordinated action of the companies involved in shared workplaces is necessary to ensure OSH. In addition, identifying hazards in general and informing the employees of all of the relevant companies about them play significant roles [6].

Good practices in shared workplaces have also been reviewed by Nenonen [6] (Table 1). She categorizes the practices that have a positive effect on safety promotion as those related to the selection, supervision of and agreements with suppliers, planning and performing work safely, efficient hazard identification, familiarization and training of employees, and common rules and cooperation practices for the employees of the service purchaser and for the providers.

Table 1. Challenges and good practices in shared workplaces based on Nenonen [6].

\begin{tabular}{ll}
\hline Challenge & Good practice \\
\hline Service provider selection & $\begin{array}{l}\text { Acts of the service purchaser in the selection } \\
\text { of and agreements with the supplying } \\
\text { company } \\
\text { Planning, scheduling and coordination of } \\
\text { work }\end{array}$ \\
Supply chains & $\begin{array}{l}\text { Supervision of safety performance } \\
\text { Resources available for safety }\end{array}$ \\
management & $\begin{array}{l}\text { Specification of the safety responsibilities of } \\
\text { the service provider }\end{array}$ \\
Responsibilities and commitment & $\begin{array}{l}\text { Safe work practices } \\
\text { Accident investigation }\end{array}$ \\
Dangerous work tasks and practices \\
Accident prevalence & $\begin{array}{l}\text { Hazard identification } \\
\text { Communication and cooperation } \\
\text { Communication }\end{array}$ \\
Attitudes and work culture & Common rules of the shared workplace \\
Competence and training & Orientation and safety training \\
\hline
\end{tabular}

To tackle the OSH challenges in workplaces, risk assessments are now mandated by law. However, the implementation and quality of risk assessments vary greatly. Kalliolinna and Alén [20] portray how the risk assessment procedure in companies could be successfully clarified through the cooperation of occupational safety inspectors and workplace representatives. They suggest simple hierarchical risk assessment methods that offer the company the possibility to concentrate on problem areas. They also stress the inclusion of employees in the risk assessment process to ensure their commitment to improving safety and increasing risk awareness [20].

The change from the traditional norm-based way of thinking to more selfdirected risk management, which is identified as a challenge by Kalliolinna and Alén [20], has created several risk assessment methods that companies can use voluntarily to improve safety. One of these is the health, safety, environment and quality (HSEQ) assessment procedure, which is especially directed at shared workplaces [2]. The 
procedure aims for holistic HSEQ management. It was developed in northern Finland in close collaboration with a university and large-scale industrial companies and is widely used in Finnish industries. The procedure is used to measure and to evaluate the HSEQ capabilities of supplier companies to ensure that they have sufficient skills and knowledge to work on the premises of a principal company.

Disruptions in the information processes of a work system and human communication have also been identified as a major factor in occupational accidents [21]. Väyrynen et al. [22] consider communication an essential factor that needs to be recognized as a capability which should be an integral aspect of every organization. To promote positive outcomes related to health and safety, as well as other facets of work life, Väyrynen et al. [22] have presented multidisciplinary work on frictionless communication. Communication plays an even more important role in crossorganizational and inter-organizational contexts, such as shared workplaces.

Recognizing the benefits of involving all of the relevant stakeholders of an organization, e.g., owners, employees and customers, in a dialogue is essential, and methods such as the previously mentioned HSEQ assessment procedure can aid in this regard [23].

\subsection{Work system model}

The work system is defined as consisting of the person or the employee, his or her work task, the tools for accomplishing the task, the environment and the organization in which the work takes place [10-12]. Work can be seen as consisting of processes that lead to either positive or negative outcomes, depending on the input and the interplay of the elements of the work system. Positive outcomes include productivity and wellbeing, while negative outcomes include discomfort, stress, errors and accidents.

Applying the work system model to more complicated situations than an individual organization, such as a network comprising several actors, requires a deeper understanding of the model. The complexity of systems that involve multiple actors has led to macroergonomics, which considers the physical, organizational, social and societal contexts of work [12].

At the macroergonomics level, the work system can be seen as consisting of several subsystems. The sociotechnical subsystem is created when the personnel subsystem interacts with the technological subsystem. The technological subsystem consists of the tools, methods and technologies needed to accomplish the work, while the personnel subsystem consists of all the employees needed to perform the work. Other subsystems are the external environment (elements outside the work system), internal environment (the cultural and physical contexts of work) and organizational (the structure and processes of the organization) subsystems. Each of these subsystems acts inside a larger system of systems that are intertwined with all the other systems [24]. This gives rise to a complex work system that requires microergonomic and macroergonomic approaches [2]. 


\section{Materials and methods}

OSH inspection reports were used to gain a holistic perspective of the conditions in shared workplaces and to answer the research questions related to the $\mathrm{OSH}$ challenges, special characteristics, situations and other phenomena related to shared workplaces from the standpoints of the various actors. The empirical data provided by the workplace inspection reports on shared workplaces were analysed by categorizing the observations made in the inspections. The framework of the work system was used in the examination. The analysis resulted in the recognition of categories on which the observations in the shared workplaces were focused. Industry-specific observation profiles were created for those industry branches, namely, the construction industry, manufacturing industry and mining and quarrying industry, for which sufficient data were available.

\subsection{Materials}

The materials for this study were OSH inspection reports $(N=200)$ from the Regional State Administrative Agency of Finland. The OSH inspections concentrate on safety risks, management of workload factors and the minimum conditions of employment. In addition to providing supervision, the inspections are also aimed at helping the workplace to develop its OSH function and safe work conditions. The inspection of the working conditions includes observations based on discussions, documents and site visits. The inspector assesses the work environment, and violations of the $\mathrm{OSH}$ legislation result in the issuance of written advice and improvement notices, which are recorded in the inspection report.

The inspections from which the data for this study were generated were conducted around Finland between 2012 and 2016. They targeted shared workplaces in different branches of industry. The reports used in this analysis were selected randomly. However, only reports indicating at least one observed deficiency that had led to written advice or an improvement notice from the agency were included in the materials. On average, each OSH inspection report contained four (range 1-17) observations. The total number of analysed observations in this study was 838 .

Half of the inspections targeted the main worksites of employers. The other half were conducted at worksites where the employer was not the principal company. However, all of the inspected workplaces could be considered shared workplaces.

The materials consist of inspection reports mainly on workplaces in the construction industry $(39.5 \%, n=79)$, manufacturing industry $(24.5 \%, n=49)$ and mining and quarrying industry $(17 \%, n=34)$ (Table 2). These industries comprise about $81 \%$ of the analysed inspection reports, while the remaining reports cover other branches of industries. The inspected employers were construction companies in $35 \%$ ( $n$ $=70)$ of cases and manufacturing industry companies in $31.5 \%(n=63)$ of cases. Employers of other branches of industries were represented in much smaller numbers. Table 2 provides an overview of the occurrence of shared workplaces in different branches of the industries. The inspection reports used for this study constitute a limited sample $(N=200)$ from the database containing all of the inspection reports. The 
Standard Industrial Classification TOL 2008 [25] was used for identifying the various industry branches. The TOL 2008 classification is based on the Statistical Classification of Economic Activities in the European Community, NACE (Nomenclature générale des Activités économiques dans les Communautés européennes), used in the EU.

Table 2. Number and percentage of analysed occupational safety and health inspection reports on each branch of industry according to the Standard Industrial Classification TOL 2008 [25].

\begin{tabular}{lcc}
\hline Industry branch & $n$ & $\%$ \\
\hline Construction & 79 & 39.5 \\
Manufacturing & 49 & 24.5 \\
Mining and quarrying & 34 & 17.0 \\
Wholesale and retail trade; repair of motor vehicles and motorcycles & 9 & 4.5 \\
Water supply; sewerage, waste management and remediation activities & 7 & 3.5 \\
Transportation and storage & 7 & 3.5 \\
Human health and social work activities & 5 & 2.5 \\
Electricity, gas, steam and air conditioning supply & 4 & 2.0 \\
Other service activities & 3 & 1.5 \\
Agriculture, forestry and fishing & 1 & 0.5 \\
Administrative and support service activities & 1 & 0.5 \\
Public administration and defence; compulsory social security & 1 & 0.5 \\
\hline
\end{tabular}

\subsection{Qualitative analysis}

The OSH inspection reports were analysed using NVivo version 11 Pro designed for analysing qualitative data. The observations that led to written advice or improvement notices from the agency were categorized thematically. This was done by applying the open coding approach, which is commonly used with the grounded theory method [26]. The categories were themes that emerged from the observations. The categorization was initially done by the researcher (P. K.). The categories were then discussed and finalized with the expert from the Regional State Administrative Agency (H.-K. R.).

The analysis resulted in 51 observation categories, each of which was also linked to the elements of the work system. Each of the observation categories contained between 2 and 66 observations from the workplace inspection reports. An observation could belong to more than one category, and an inspection report could have more than one observation that belonged to a specific category. The 838 analysed observations from the OSH inspection reports thus resulted in 918 observation references (hereafter referred to as observations) to the various categories.

To gather additional details on the special situations of organizing work in shared workplaces, the sections of the Finnish Occupational Safety and Health Act (738/2002, Chapter 6, §49-55) [15] indicated in the written advice and the improvement notices documented in the inspection reports were examined. $\chi 2$ tests were performed for the number of observations related to each work system element to determine whether there were significant differences among the industry branches. This was 
accomplished using SPSS Statistics version 25. The level of statistical significance was defined as $\mathrm{p}<0.05$.

\section{Results}

The number of categorized observations and the relationship of these observations to the elements of the work system are examined in Subsection 4.1 in answer to Research Question 1: 'What kinds of OSH challenges exist in shared workplaces?' In this subsection, the special situations of organizing work are also viewed through the citations of legislation in the reports to answer Research Question 2: 'How do the situations of special work take place in practice when viewed from the standpoints of the various actors involved?' The industry-specific observation profiles for the main branches of industry included in the materials are then presented in Subsection 4.2 to answer Research Question 3: 'What are the special characteristics, situations and phenomena related to shared workplaces in different branches of industries?'

\subsection{Challenges in shared workplaces according to OSH inspection reports}

The categories that contain the most observations are presented with their respective percentages in Table 3. These 10 most prominent categories contain approximately half $(52.2 \%, n=479)$ of all the observations. According to the analysed material, these are the main challenges in shared workplaces. The total number of observations in the various categories are naturally affected by the industry branches that are overrepresented in the materials, namely the construction, manufacturing and mining and quarrying industries (Table 2).

When the categorized observations $(n=918)$ are viewed through the work system framework, it can be seen that observations related to the organization account for $39.2 \%(n=361)$ of the observations, while $27.6 \%(n=253)$ are linked to the work environment, $19.6 \%(n=180)$ to tools, only $8.1 \%(n=74)$ to the employee and $5.5 \%(n$ $=50)$ to the work task.

Table 3. Ten most prominent categories with their respective number and percentage proportion of all observations.

\begin{tabular}{lcc}
\hline Observation category & $n$ & $\%$ \\
\hline Fall hazard & 66 & 7.2 \\
Accessways & 60 & 6.5 \\
Use of personal protective equipment & 58 & 6.3 \\
Planning deficiencies & 56 & 6.1 \\
Identification and assessment of hazards at work & 48 & 5.2 \\
Condition and suitability of tools & 45 & 4.9 \\
Exposure to chemical agents & 42 & 4.6 \\
Safety guards and protective devices & 41 & 4.5 \\
Order and tidiness & 34 & 3.7 \\
Inspections of devices and tools & 29 & 3.2 \\
\hline
\end{tabular}


Table 4, on the other hand, presents the 10 largest observation categories for which legislation related to shared workplaces is the most frequently cited of all observations. Because of the slight discrepancy in the number of cited articles contained in the inspection reports, these findings can be regarded as only qualitative and not quantitative. When the most frequently occurring observation categories are compared, the results are similar to those for the total number of categorized observations presented in Table 3 and the industry-specific results presented in the next subsection. The categories for supervision, cooperation and communication among actors, danger of falling or collapse of materials and marking off the construction site occur more frequently in the results of this examination as compared to other results.

Table 4. Observation categories among which the legislation related to shared workplaces is most frequently cited in the workplace inspection reports.

\begin{tabular}{lcc}
\hline Observation category & $n$ & $\%$ \\
\hline Planning deficiencies & 83 & 14.6 \\
Use of personal protective equipment & 53 & 9.3 \\
Fall hazard & 52 & 9.2 \\
Supervision & 48 & 8.5 \\
Accessways & 45 & 7.9 \\
Cooperation and communication among actors & 35 & 6.2 \\
Exposure to chemical agents & 34 & 6.0 \\
Danger of falling or collapse of materials & 28 & 4.9 \\
Condition and suitability of tools & 27 & 4.8 \\
Marking off the construction site & 18 & 3.2 \\
\hline
\end{tabular}

The sections of the Occupational Safety and Health Act [15] of Finnish legislation related to shared workplaces that were most cited in the reports dealt with obligations on a shared construction site $(n=248)$, obligations of the employer exercising the main authority in a shared workplace $(n=112)$, the duty of those operating in a shared workplace to exercise care $(n=105)$, information and cooperation in a shared workplace $(n=78)$ and, in much smaller numbers, obligations of selfemployed workers in a shared workplace $(n=8)$, list of persons working on a shared construction site $(n=5)$, identification of persons working on a shared construction site $(n=5)$ and elimination of mutual hazards in workplaces $(n=4)$.

The number of observations in each category as a percentage of all observations is presented in Figures 1-5 in accordance with the elements of the work system. For clarity, the categories related to the organization are further divided into subsets of human resources and documentation, safety management, OSH, occupational health services and general practices.

In observations related to the organization (Figure 1), the planning deficiencies and identification and assessment of hazards at work stand out. Observations related to planning deficiencies included the following entries, which are quoted from the material: 'Written documents of safety plans had not been drawn up and were also not available at the work site' (Report No. 142) and 'There were no final plans regarding 
the coordination of the passage of the residents and the execution of the construction work' (Report No. 144).

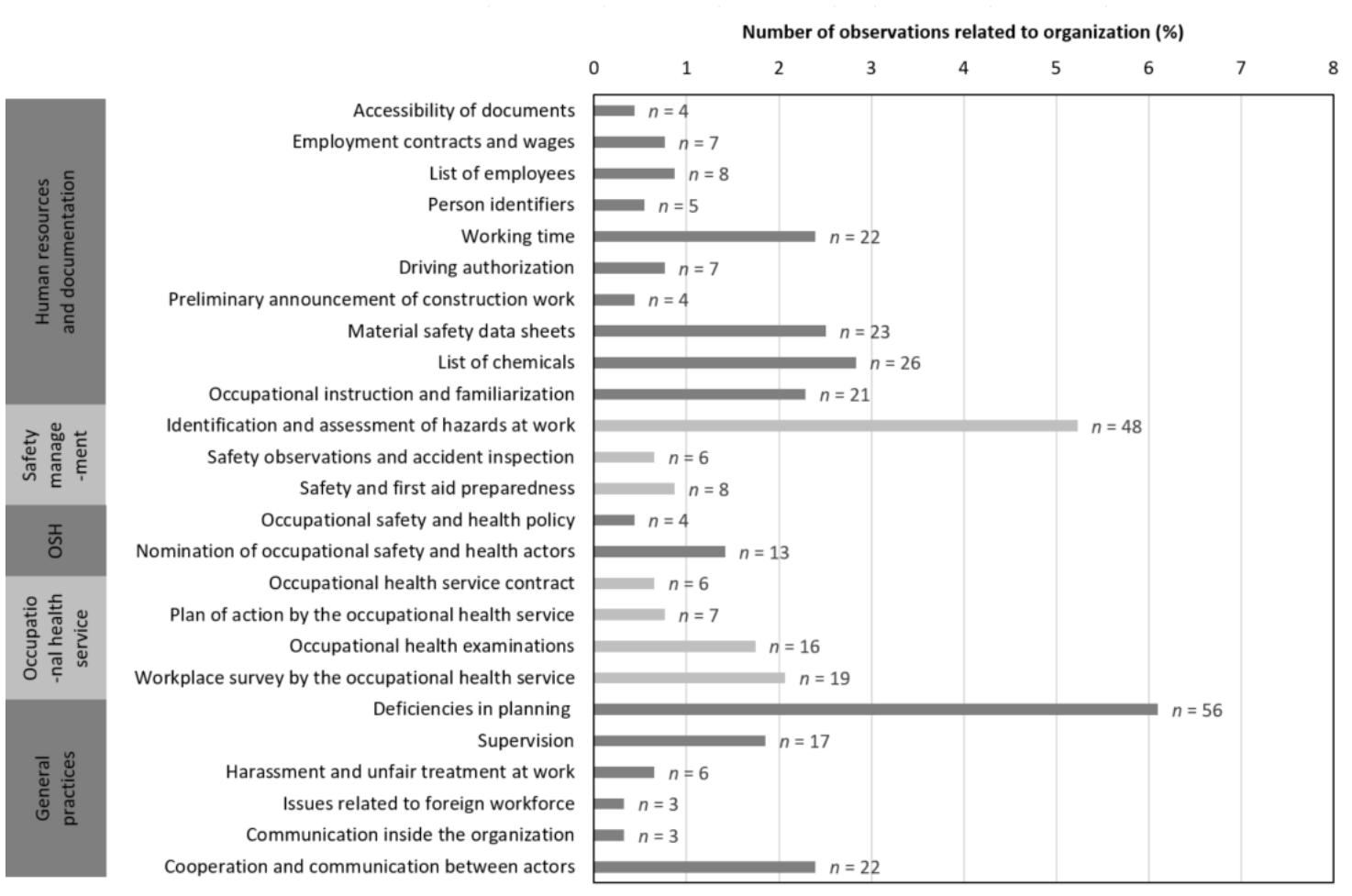

Figure 1. Number of observations in each category related to the organization as a percentage of all observations. Note: $\mathrm{OSH}=$ occupational safety and health.

Regarding observations related to the employee (Figure 2), the use of personal protective equipment (PPE) is the most notable of the two categories. This included observations such as: 'There were employees who were not wearing safety helmets or reflective safety clothing at the worksite' (Report No. 146), 'The employee working on the heavy-duty vibrator for construction work was not wearing hearing protectors' (Report No. 136) and 'Chain saw was used at the work site without appropriate personal protectors against cuts, which were specified in the user manual of the saw' (Report No. 76).

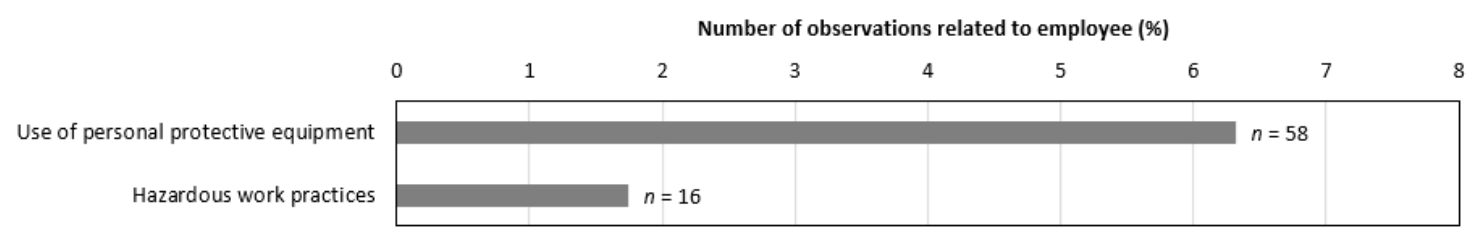

Figure 2. Number of observations in each category related to the employee as a percentage of all observations.

The observations related to the work task (Figure 3) showed a peak in the category exposure to chemical agents. The observations in this category included: 'The exhaust fumes from the combustion engine powered work machines were not ventilated from the work space efficiently enough' (Report No. 135) and 'Asbestos demolition 
procedures defined in the legislation were not used in the demolition of the rectangular duct' (Report No. 141).

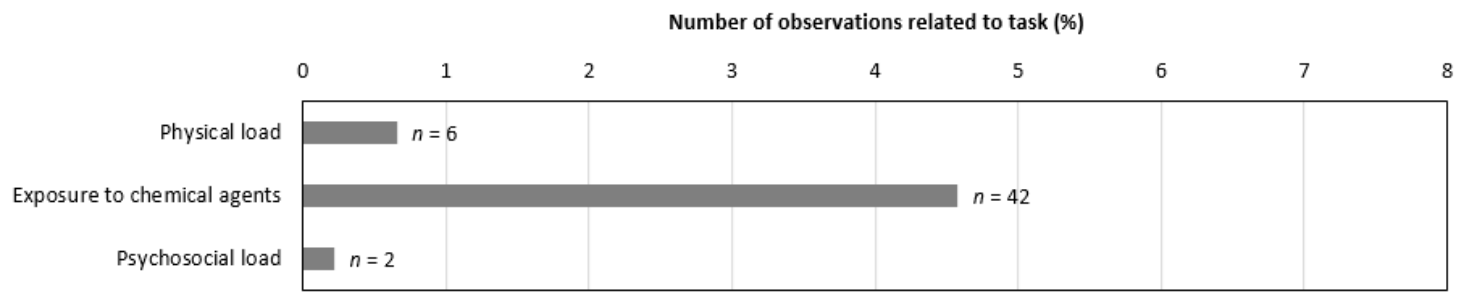

Figure 3. Number of observations in each category related to the work task as a percentage of all observations.

The tools and technology element (Figure 4) shows a peak in the categories of safety guards and protective devices as well as the condition and suitability of tools. Related to the condition and suitability of tools, the following observations were found in the materials: 'There was an A-shape ladder exceeding the height of 1 meter that was used as an ascension path from the pit at the work site. The ladder was not used as was instructed in the manual' (Report No. 76) and 'The deficiencies marked in the scheduled inspection report of the tower crane X (crane no. M) had not been corrected by the due date given by the inspector' (Report No. 136).

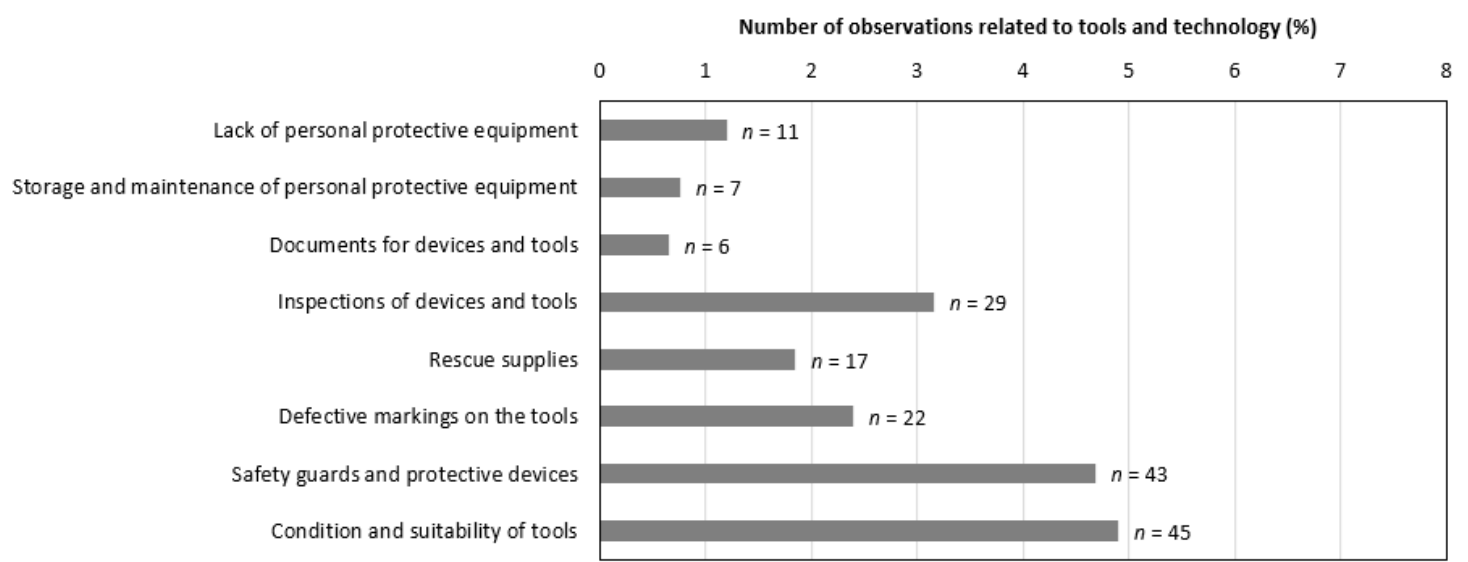

Figure 4. Number of observations in each category related to tools and technology as a percentage of all observations.

Finally, in terms of the work environment (Figure 5), accessways and fall hazard were the dominant categories. One observation stated that: 'The employees working on the roof were not wearing safety harnesses, and there were no railings on the roof to prevent falling. The height of the drop from the roof was approximately $8 \mathrm{~m}$. The access to the roof was realised using a scissor lift, which is not allowed according to the operating instructions for the lift type in question.' (Report No. 70) Another observation was that 'There was an unprotected opening at the work platform between the scaffolding and the facade' (Report No. 134). These observations are listed under the category fall hazard. 


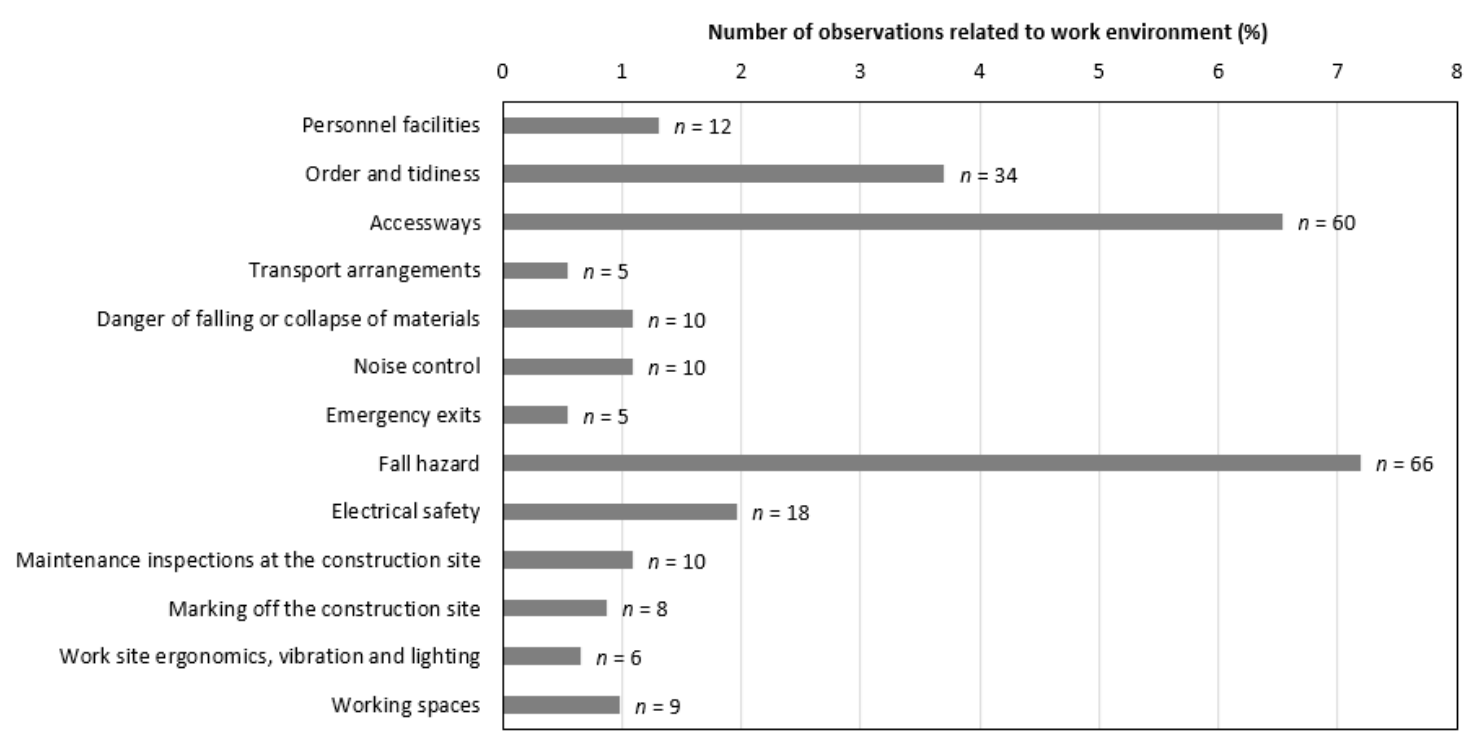

Figure 5. Number of observations in each category related to the work environment as a percentage of all observations.

\subsection{Industry-specific observation profiles}

The industry-specific observation profiles presented in the following were created according to the industry branch of the worksite where the inspection took place. This means that an inspection which takes place on a construction site, e.g., is regarded as a construction industry case even if the inspection targets an employer whose area of expertise is electrical installation. Thus, a branch of the worksite can be considered a main contributor to the possible hazards and deficiencies observed during the inspection. In addition, focusing on the worksites versus looking at the industry branch of the employer company resulted in no significant difference in the outcome.

The branches of construction $(n=79)$, manufacturing $(n=49)$ and mining and quarrying $(n=34)$ were represented sufficiently in the number of analysed inspection reports so that industry-specific observation profiles could be created. Shared workplaces are also very common among these industries. The industry-specific observation profiles for these branches are presented in Table 5. The profile comprises all of the observation categories, which, for clarity, are represented as clusters based on the divisions of the work system model. In addition, subsets were used for the categories related to the organization. The number of observations ( $\left.n \_o b s\right)$ and their proportions, expressed as percentages, to the total number of observations for the industry branch are presented. The observation categories with the most observations in each industry branch are indicated by bold font.

In addition to the categories in which most of the observations fall, the gaps in the observation profiles, i.e., the categories for which there are no observations or only a few, offer interesting information. To explore the gaps, background information on the checklists used in the inspections is needed. Each industry branch has its own observation profile, which can be used, e.g., in the design of industry-specific inspection checklists. 
In the organization section of Table 5, it can be seen that observations related to planning deficiencies are predominant in the construction industry, while identification and assessment of hazards at work and cooperation and communication among actors are the dominant categories in the manufacturing industry. Working time shows a peak in the values for the mining and quarrying industry. Regarding the observation categories related to the employee, the biggest difference among the studied industries is that observations about the use of PPE are pronounced in the construction industry. For the categories related to the task, exposure to chemical agents is pronounced in the mining and quarrying industry. When the observation categories under tools and technologies are examined, the condition and suitability of tools arises, especially in the construction and mining and quarrying industries. In the manufacturing industry, defective safety guards and protective devices can also be observed. Regarding issues related to the work environment, the observations related to accessways and fall hazard are common in the construction industry, while lack of order and tidiness lead to observations in the mining and quarrying industry often as a result of dust on the worksite and personnel facilities.

Table 5. Number of observations ( $\left.n \_o b s\right)$ and percentage proportion of the observations in each category of all observations in the industry branches of construction, manufacturing industry and mining and quarrying.

\begin{tabular}{|c|c|c|c|c|}
\hline \multirow[b]{2}{*}{$\begin{array}{l}\text { Work system } \\
\text { element }\end{array}$} & \multirow[b]{2}{*}{ Observation category } & \multicolumn{3}{|c|}{ Industry } \\
\hline & & $\begin{array}{l}\text { Construc- } \\
\text { tion, } n \_o b s \\
\quad(\%)\end{array}$ & $\begin{array}{c}\text { Manufac- } \\
\text { turing, } n \_o b s \\
(\%)\end{array}$ & $\begin{array}{l}\text { Mining and } \\
\text { quarrying, } \\
n \_o b s(\%)\end{array}$ \\
\hline \multicolumn{5}{|l|}{ Organization } \\
\hline Human resources & Accessibility of documents & $0(0.0)$ & $0(0.0)$ & $1(0.6)$ \\
\hline \multirow[t]{9}{*}{$\begin{array}{r}\text { and } \\
\text { documentation }\end{array}$} & $\begin{array}{l}\text { Employment contracts and } \\
\text { wages }\end{array}$ & $2(0.4)$ & $0(0.0)$ & $2(1.2)$ \\
\hline & List of employees & $8(1.7)$ & $0(0.0)$ & $0(0.0)$ \\
\hline & Person identifiers & $5(1.1)$ & $0(0.0)$ & $0(0.0)$ \\
\hline & Working time & $2(0.4)$ & $4(2.9)$ & $10(5.9)$ \\
\hline & Driving authorisation & $4(0.9)$ & $1(0.7)$ & $1(0.6)$ \\
\hline & $\begin{array}{l}\text { Preliminary announcement of } \\
\text { construction work }\end{array}$ & $4(0.9)$ & $0(0.0)$ & $0(0.0)$ \\
\hline & Material safety data sheets & $18(3.9)$ & $2(1.5)$ & $0(0.0)$ \\
\hline & List of chemicals & $16(3.5)$ & $1(0.7)$ & $5(2.9)$ \\
\hline & $\begin{array}{l}\text { Occupational instruction and } \\
\text { familiarisation }\end{array}$ & $7(1.5)$ & $6(4.4)$ & $3(1.8)$ \\
\hline \multirow[t]{3}{*}{$\begin{array}{r}\text { Safety } \\
\text { management }\end{array}$} & $\begin{array}{l}\text { Identification and assessment of } \\
\text { hazards at work }\end{array}$ & $5(1.1)$ & $17(12.5)$ & $7(4.1)$ \\
\hline & $\begin{array}{l}\text { Safety and first aid } \\
\text { preparedness }\end{array}$ & $0(0.0)$ & $2(1.5)$ & $2(1.2)$ \\
\hline & $\begin{array}{l}\text { Safety observations and } \\
\text { accident inspection }\end{array}$ & $0(0.0)$ & $4(2.9)$ & $0(0.0)$ \\
\hline
\end{tabular}




\begin{tabular}{|c|c|c|c|c|}
\hline $\begin{array}{r}\text { Occupational } \\
\text { safety and health }\end{array}$ & $\begin{array}{l}\text { Occupational safety and health } \\
\text { policy }\end{array}$ & $0(0.0)$ & $1(0.7)$ & $0(0.0)$ \\
\hline & $\begin{array}{l}\text { Nomination of occupational } \\
\text { safety and health actors }\end{array}$ & $3(0.7)$ & $1(0.7)$ & $3(1.8)$ \\
\hline \multirow[t]{4}{*}{$\begin{array}{r}\text { Occupational } \\
\text { health services }\end{array}$} & $\begin{array}{l}\text { Occupational health service } \\
\text { contract }\end{array}$ & $0(0.0)$ & $1(0.7)$ & $2(1.2)$ \\
\hline & $\begin{array}{l}\text { Occupational health service } \\
\text { plan of action }\end{array}$ & $1(0.2)$ & $2(1.5)$ & $3(1.8)$ \\
\hline & $\begin{array}{l}\text { Occupational health } \\
\text { examinations }\end{array}$ & $3(0.7)$ & $2(1.5)$ & $8(4.7)$ \\
\hline & $\begin{array}{l}\text { Occupational health service } \\
\text { workplace survey }\end{array}$ & $2(0.4)$ & $3(2.2)$ & $6(3.5)$ \\
\hline \multirow{6}{*}{$\begin{array}{r}\text { General } \\
\text { practices }\end{array}$} & Planning deficiencies & $55(12.0)$ & $0(0.0)$ & $1(0.6)$ \\
\hline & Supervision & $15(3.3)$ & $2(1.5)$ & $0(0.0)$ \\
\hline & $\begin{array}{l}\text { Harassment and unfair } \\
\text { treatment at work }\end{array}$ & $0(0.0)$ & $3(2.2)$ & $0(0.0)$ \\
\hline & $\begin{array}{l}\text { Issues related to foreign } \\
\text { workforce }\end{array}$ & $2(0.4)$ & $0(0.0)$ & $1(0.6)$ \\
\hline & $\begin{array}{l}\text { Communication inside the } \\
\text { organisation }\end{array}$ & $0(0.0)$ & $2(1.5)$ & $1(0.6)$ \\
\hline & $\begin{array}{l}\text { Cooperation and } \\
\text { communication among actors }\end{array}$ & $11(2.4)$ & $8(5.9)$ & $0(0.0)$ \\
\hline \multirow[t]{2}{*}{ Employee } & $\begin{array}{l}\text { Use of personal protective } \\
\text { equipment }\end{array}$ & $51(11.1)$ & $5(3.7)$ & $0(0.0)$ \\
\hline & Hazardous work practices & $7(1.5)$ & $1(0.7)$ & $4(2.4)$ \\
\hline \multirow[t]{3}{*}{ Task } & Physical load & $0(0.0)$ & $4(2.9)$ & $1(0.6)$ \\
\hline & Exposure to chemical agents & $13(2.8)$ & $5(3.7)$ & $18(10.6)$ \\
\hline & Psychosocial load & $0(0.0)$ & $2(1.5)$ & $0(0.0)$ \\
\hline \multirow[t]{8}{*}{$\begin{array}{l}\text { Tools and } \\
\text { technology }\end{array}$} & $\begin{array}{l}\text { Lack of personal protective } \\
\text { equipment }\end{array}$ & $7(1.5)$ & $2(1.5)$ & $2(1.2)$ \\
\hline & $\begin{array}{l}\text { Storage and maintenance of } \\
\text { personal protective equipment }\end{array}$ & $2(0.4)$ & $2(1.5)$ & $3(1.8)$ \\
\hline & $\begin{array}{l}\text { Documents for devices and } \\
\text { tools }\end{array}$ & $0(0.0)$ & $1(0.7)$ & $5(2.9)$ \\
\hline & Inspections of devices and tools & $20(4.4)$ & $1(0.7)$ & $4(2.4)$ \\
\hline & Rescue supplies & $4(0.9)$ & $1(0.7)$ & $5(2.9)$ \\
\hline & Defective markings on the tools & $13(2.8)$ & $2(1.5)$ & $2(1.2)$ \\
\hline & $\begin{array}{l}\text { Safety guards and protective } \\
\text { devices }\end{array}$ & $7(1.5)$ & 15 (11.0) & $9(5.3)$ \\
\hline & $\begin{array}{l}\text { Condition and suitability of } \\
\text { tools }\end{array}$ & $23(5.0)$ & $4(2.9)$ & $13(7.6)$ \\
\hline \multirow{3}{*}{$\begin{array}{l}\text { Work } \\
\text { environment }\end{array}$} & Personnel facilities & $5(1.1)$ & $1(0.7)$ & $4(2.4)$ \\
\hline & Order and tidiness & $15(3.3)$ & $2(1.5)$ & $12(7.1)$ \\
\hline & Accessways & $43(9.4)$ & $8(5.9)$ & $5(2.9)$ \\
\hline
\end{tabular}




\begin{tabular}{|c|c|c|c|}
\hline Transport arrangements & $1(0.2)$ & $1(0.7)$ & $1(0.6)$ \\
\hline $\begin{array}{l}\text { Danger of falling or collapse of } \\
\text { materials }\end{array}$ & $9(2.0)$ & $0(0.0)$ & $1(0.6)$ \\
\hline Noise control & $1(0.2)$ & $4(2.9)$ & $3(1.8)$ \\
\hline Emergency exits & $2(0.4)$ & $0(0.0)$ & $1(0.6)$ \\
\hline Fall hazard & $48(10.5)$ & $4(2.9)$ & $8(4.7)$ \\
\hline Electrical safety & $6(1.3)$ & $4(2.9)$ & $6(3.5)$ \\
\hline $\begin{array}{l}\text { Maintenance inspections at the } \\
\text { construction site }\end{array}$ & $10(2.2)$ & $0(0.0)$ & $0(0.0)$ \\
\hline $\begin{array}{l}\text { Marking off the construction } \\
\text { site }\end{array}$ & $6(1.3)$ & $2(1.5)$ & $0(0.0)$ \\
\hline $\begin{array}{l}\text { Work site ergonomics, vibration } \\
\text { and lighting }\end{array}$ & $2(0.4)$ & $1(0.7)$ & $2(1.2)$ \\
\hline Working spaces & $1(0.2)$ & $2(1.5)$ & $5(2.9)$ \\
\hline
\end{tabular}

Note: The observation categories with the most observations in each industry branch are indicated by bold font.

Figure 6 presents the condensed forms of the visualized industry-specific observation profiles in the industry branches of construction, manufacturing industry and mining and quarrying as numbers of observations in each work system element as a percentage of all observations.

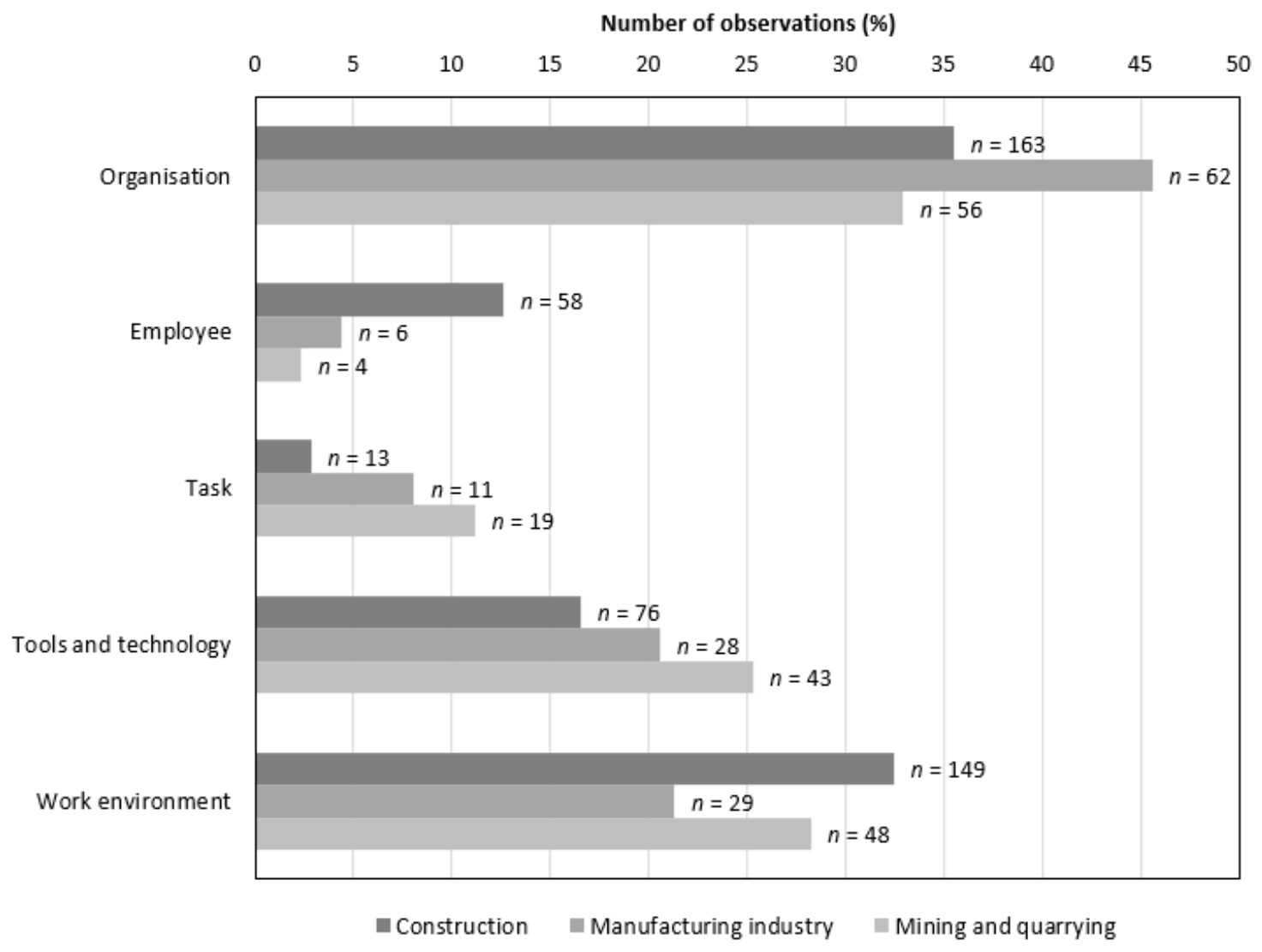


Figure 6. Number of observations in each work system element as a percentage of all observations in the industry branches of construction, manufacturing industry and mining and quarrying.

A $\chi 2$ test was performed to compare the results of the industry branches. Because of the low number of observations in several individual observation categories, the test was performed by weighting cases by the organization, employee, task, tools and technology and work environment variables. The $p$ values given by the $\chi 2$ tests are presented in Table 6 for each pair of industries. In the case of categories related to organization, the results show a significant difference $(p<0.05)$ between the construction and manufacturing industries and between the manufacturing industry and the mining and quarrying industry. For both categories related to employee and task, there is a significant difference between the construction and manufacturing industries as well as the construction and the mining and quarrying industries. Regarding tools and technology, a significant difference can be observed between the construction industry and the mining and quarrying industry, while in case of the work environment there is a significant difference between the construction and manufacturing industries.

Table $6 . \chi 2$ test $p$ values weighted by work system elements.

\begin{tabular}{lccc}
\hline & \multicolumn{3}{c}{$p$} \\
\cline { 2 - 4 } & $\begin{array}{c}\text { Construction } \\
\text { industry } \\
\text { manufacturing } \\
\text { industry }\end{array}$ & $\begin{array}{c}\text { Construction } \\
\text { industry }- \text { mining } \\
\text { and quarrying } \\
\text { industry }\end{array}$ & $\begin{array}{c}\text { Manufacturing } \\
\text { industry }- \text { mining } \\
\text { and quarrying } \\
\text { industry }\end{array}$ \\
\hline Organization & $0.033^{*}$ & 0.548 & $0.024^{*}$ \\
Employee & $0.007^{*}$ & $<0.001^{*}$ & 0.314 \\
Task & $0.006^{*}$ & $<0.001^{*}$ & 0.367 \\
Tools and technology & 0.277 & $0.013^{*}$ & 0.333 \\
Work environment & $0.013^{*}$ & 0.310 & 0.166 \\
\hline
\end{tabular}

*Statistically significant differences $(p<0.05)$.

\section{Discussion}

The method presented in the previous sections enables the formation of OSH profiles for any branch of industry based on the existing workplace inspection reports. These profiles point out the most common challenges of the industry branch in question, and can provide valuable information for OSH supervision, development and management about the issues which to focus on. We highlight the complexity of shared workplaces and we also recognize the need for new approaches to OSH management. For instance, the recently published Standard No. ISO 45001:2018 [27] on occupational health and safety management systems also recognizes the challenges present in shared workplaces and guides organizations to treat all actors according to shared health and safety instructions. 
The division according to the elements of the work system framework provides a view that is holistic and encompasses the various sections of work, while individual categories provide information on a microergonomic level that is relevant from the viewpoint of an individual employee. Similar profiles can be used in the case of individual workplaces as well, although in this study the material comprised workplace inspection reports on shared workplaces.

The good practices in shared workplaces presented in Table 1 [6] included planning, scheduling and coordination of work. In this study, the observation categories related to organization showed a peak in planning deficiencies in the construction industry. Deficiencies in planning have been identified as a challenge and a common factor of accidents in shared workplaces in various industries in earlier studies as well $[16,28]$. In the construction industry, planning has a major role in terms of safety of the operations due to constantly changing construction sites, while, e.g., in the manufacturing industry and to some extent also in the mining and quarrying industry the worksites are more stable by nature.

Also presented as good practices in Table 1 [6] are hazard identification and safe work practices. In our results, especially in the manufacturing industry, the identification and assessment of hazards at work emerged in the observations. Hazard identification, especially in terms of the safety of the service provider's employees, has also been identified as a challenge in earlier research $[4,6]$. In the construction industry, deficiencies related to accessways and fall hazard were also mentioned frequently in the inspection reports. These are common factors for accidents in the construction industry [16]. Related to tools and technology, the condition and suitability of tools as well as safety guards and protective devices were major factors in the mining and quarrying and the manufacturing sectors.

Communication and cooperation as well as specification of the safety responsibilities of the service provider have self-evidently been identified as good practices in shared workplaces (Table 1) [6]. In the present study, the observations related to cooperation and communication among actors constituting only $2.4 \%$ of all observations was somewhat surprising. Although communication has been identified as a challenge in shared workplaces in several earlier studies [6], some studies also suggest that communication problems are not as common an accident factor in shared workplaces as is often expected [5]. Altogether, these findings are in line with the larger scale challenges in shared workplaces identified by Nenonen [6] and presented in Table 1. As a conclusion, we emphasize that OSH development actions on these branches of industries should be targeted at these main challenges. In addition, we point out, based on our study, that the OSH profiles should be used when planning OSH management in shared workplaces and also for focusing OSH authority actions. As a future research question we raise whether these profiles would be similar when shared and individual workplaces are compared. However, we also point out that such a comparison could be difficult to arrange, as in practice the workplaces in the branches covered are most often shared workplaces and individual workplaces do not necessarily exist.

The results of this study are limited by the fact that the OSH inspections and the written advice and improvement notices given to employers based on the observed 
deficiencies are based on Finnish legislation [15]. Because the guidelines are based on legislation, reaching and maintaining certain minimum standards are enough to avoid notices; thus, challenges or good practices not covered by the legislation are not included in this examination. Further, we point out that the profiles formed in this study encompass the health and safety aspects through workplace inspection reports. Often in industrial contexts, health and safety management is integrated into environment and quality management and discussed as integrated HSEQ (or EHSQ or other similar acronym) management. We point out as a future research question that the aspects related to environment and quality could also be worth profiling with other means.

The data were somewhat unevenly distributed across the various branches of the industries. This was taken into account by omitting industries with a low number of reports from the industry-specific examination. This data are included, however, in the examination of the total number of categorized observations. The variance in the level of detail in the written reports was also identified as a challenge. The reports are written by individual supervisors, and despite their consistent training, each individual reflects his or her view in the reports.

For future research, using a larger data set that covers the branches of the industries where shared workplaces exist evenly could offer deeper insights into the conditions in shared workplaces. Creating industry-specific observation profiles based on more data and spanning a larger number of industries could be useful for targeting supervision at the identified challenges of each industry. In the long term, focusing the OSH development actions on identified challenges and following the effects of these actions would serve as an important and interesting subject for study.

\section{Conclusions}

The goal of this study was to present a holistic view of the conditions in shared workplaces and to shed light on how these 'special situations' for organizing work take place in practice. The materials used in the study were focused on industries in which shared workplaces are most commonly identified: namely, the construction, manufacturing, mining and quarrying, transportation and storage industries. According to the findings of this study, a shared workplace can be seen as a workplace where the interactive cooperation of several actors on a collective worksite is emphasized but where each of the actors also has their own responsibilities.

The ongoing developments related to outsourcing and complex networks are based on the cooperation of several companies. This is creating situations and worksites that have characteristics similar to those of shared workplaces but do not completely fit the definition for shared workplaces. Industrial parks, shopping centres and SSCs are among some of the other entities that have characteristics similar to those of shared workplaces. In the future, these ways of organizing work might become more widespread.

The practical implication of the findings from this study is information that could be used in designing OSH inspections of shared workplaces in various branches of industries so that the supervision could be focused on the previously observed 
challenges which are characteristic of each branch. Additional work is needed to create more detailed industry-specific observation profiles for a wider range of industry branches; however, the current work presents a systematic method for analysing OSH reports.

This study also highlighted the paucity of research on shared workplaces. The concept of the shared workplace is used mainly in the Finnish context, although a similar arrangement has been identified in EU legislation. Identifying shared workplaces as a distinct group of workplaces that share common characteristics, challenges and phenomena related to OSH could aid in developing the operation and OSH culture at sites in which more than one employer operates. In sum, the changes in today's work life to increased outsourcing and the creation of more networks of organizations working together are creating a situation in which shared workplaces or other situations with similar characteristics will become much more common.

\section{Acknowledgments}

This study was conducted as part of the 'Shared Workplaces - Research, Supervision and Communications Project' of the Occupational Safety and Health Section of the Regional State Administrative Agency (AVI) of Northern Finland.

\section{References}

[1] Schulz V, Brenner W. Characteristics of shared service centers. Transforming Government: people. Proc Pol. 2010;4(3):210-219.

[2] Väyrynen S, Jounila H, Latva-Ranta J, et al. HSEQ assessment procedure for supplying network: a tool for promoting sustainability and safety culture in SMEs. In: Arezes P, Rodrigues de Carvalho PV, editors. Ergonomics and human factors in safety management. Boca Raton (FL): CRC Press; 2016. p. 83-108.

[3] Koivupalo M, Junno H, Väyrynen S. Integrated management within a Finnish industrial network: steel mill case of HSEQ assessment procedure. In: Väyrynen S, Häkkinen K, Niskanen T, editors. Integrated occupational safety and health management: solutions and industrial cases. Cham: Springer; 2015. p. 41-67.

[4] Nenonen S. Fatal workplace accidents in outsourced operations in the manufacturing industry. Saf Sci. 2011;49:1394-1403. doi:10.1016/j.ssci.2011.06.004

[5] Rantanen E, Mäkelä T, Sauni S, et al. Yhteisten työpaikkojen työturvallisuus. TOTraporttien analyysi [Occupational safety of shared workplaces. Analysis of TOT reports]. Tampere: VTT; 2007. Finnish.

[6] Nenonen S. Implementation of safety management in outsourced services in the manufacturing industry [dissertation]. Tampere: Tampere University of Technology; 2012. (Publication 1023).

[7] Väyrynen S, Koivupalo M, Latva-Ranta J. A 15-year development path of actions towards an integrated management system: description, evaluation and safety effects within the process industry network in Finland. Int J Strateg Eng Asset Manage. 2012;1(1):3-32. doi:10.1504/IJSEAM.2012.044986 
[8] Heikkilä AM, Malmén Y, Nissilä M, et al. Challenges in risk management in multicompany industrial parks. Saf Sci. 2010;48:430-435. doi:10.1016/j.ssci.2009.12.008

[9] Kekkonen P, Pohjosenperä T, Kantola H, et al. Rational and participative task allocation between the nursing staff and the logistics support service provider in healthcare. Hum Factors Ergon Manuf Serv Ind. 2018;28(3):117-129. doi:10.1002/hfm.20728

[10] Smith MJ, Sainfort PC. A balance theory of job design for stress reduction. Int J Ind Ergon. 1989;4:67-79. doi:10.1016/0169-8141(89)90051-6

[11] Carayon P, Smith MJ. Work organization and ergonomics. Appl Ergon. 2000;31:649-662. doi:10.1016/S0003-6870(00)00040-5

[12] Carayon P. The balance theory and the work system model . . twenty years later. Int J Hum-Comput Interact. 2009;25(5):313-327. doi:10.1080/10447310902864928

[13] Directive 89/391/EC of the European Parliament and of the Council of 12 June 1989 on the introduction of measures to encourage improvements in the safety and health of workers at work. OJ. 1989:L183:1-14.

[14] Directive 92/57/EC of the European Parliament and of the Council of 24 June 1992 on the implementation of minimum safety and health requirements at temporary or mobile constructions sites. OJ. 1992:L245:1-21.

[15] Occupational Safety and Health Act (738/2002). Chapter 6: special situations of organising work. Helsinki: Ministry of Social Affairs and Health; 2002.

[16] Häkkinen K, Niemelä V. Accident sources and prevention in the construction industry - some recent developments in Finland. In: Väyrynen S, Häkkinen K, Niskanen T, editors. Integrated occupational safety and health management: solutions and industrial cases. Cham: Springer; 2015. p. 17-24.

[17] Turunen H, Väyrynen S, Lehtinen U. Introducing a scenario of a seaport's HSEQ framework: review and a case in northern Finland. In: Väyrynen S, Häkkinen K, Niskanen T, editors. Integrated occupational safety and health management: solutions and industrial cases. Cham: Springer; 2015. p. 69-94.

[18] Teperi AM. Improving the mastery of human factors in safety critical ATM organisation [dissertation]. Helsinki: Faculty of Behavioural Sciences, University of Helsinki; 2012.

[19] Reiman A, Väyrynen S, Putkonen A. Truck drivers' work systems in environments other than the cab - a macro ergonomics development approach. In: Väyrynen S, Häkkinen K, Niskanen T, editors. Integrated occupational safety and health management: solutions and industrial cases. Cham: Springer; 2015. p. 97-110.

[20] Kalliolinna H, Alén H. Developing workplace risk assessment in Finland. Magazine of the European Agency for Safety and Health at Work. 2008;(11):26-28.

[21] Saari J. Accidents and disturbances in the flow of information. J Occup A. 1984;6:91-105. doi:10.1016/0376-6349(84)90037-3

[22] Väyrynen S, Kisko K, Filppa H, et al. Enablers of optimal work systems in industry - review, framework and Likert-scale survey for improving intra-organisational 
communication of Finnish case companies. In: Lorenz P, Dini P, editors. Proceedings of COLLA 2014: The Fourth International Conference on Advanced Collaborative Networks, Systems and Applications; 2014 June 22-26; Seville. Wilmington (DE): IARIA; 2014. p. 12-20.

[23] Väyrynen S. Quality of work system and HSEQ culture: views on ICT based on review, cases and tentative list of future key factors. In: Kommers P, editor. Proceedings of the International Conference ICT, Society and Human Beings 2017 in Multi Conference on Computer Science and Information Systems (MCCSIS); 2017 July 20-23; Lisbon. International Association for Development of the Information Society; 2017. p. 58-64.

[24] Kleiner BM, HendrickHW. Human factors in organizational design and management of industrial plants. Int J Technol Human Interact. 2008;4(1):113127. doi:10.4018/jthi.2008010107

[25] Statistics Finland. Standard Industrial Classification TOL 2008. Helsinki: Statistics Finland; 2018.

[26] Flick U. An introduction to qualitative research. 4th ed. London: SAGE; 2009.

[27] International Organization for Standardization (ISO). Occupational health and safety management systems: requirements with guidance for use. Geneva: ISO; 2018. Standard No. ISO 45001:2018.

[28] Lind-Kohvakka S. Application of accident information to safety promotion - case industrial maintenance. In: Väyrynen S, Häkkinen K, Niskanen T, editors. Integrated occupational safety and health management. Solutions and industrial cases. Cham: Springer; 2015. p. 25-37. 